\title{
REPORT OF THE BUSINESS SESSIONS OF COMMISSION 22 - METEORS AND INTERPLANETARY DUST DURING THE 22 GENERAL ASSEMBLY IN THE NETHERLANDS
}

\section{MEETING ON THURSDAY AUGUST 18 at $16 \mathrm{~h}$.}

The Acting President, Prof I.P.Williams took the chair and Proposed that Dr R.W. Hawkes be elected Secretary. The proposal was approved unanimously by the meeting.

The commission stood in silence in memory of members of the commission who had been reported as having died since the last General Assembly, namely

\author{
H. Hasegawa, \\ V. Kostyev \\ L. Kresak \\ Z. Kviv \\ V. Lebedinets \\ V. Padavet \\ J. Stohl \\ I. Shestaka
}

A special session of commissions 15, 20 and 21 would be held on Friday August 19, devoted to the highlights of research in the Solar System, to commemorate the lives of Jan Stohl, President of commission 22 at the time of his death and Lubor Kresak, a past President of both commissions 15 and 20. A conference in memory of these two great Slovak Astronomers was also to be held in Bratislava August 28-31.

A short report of the activities of the commission during the last three years was given by Prof Williams. Following the death of Dr Stohl, Prof Williams (Vice President ) had taken on the role of acting President, while Dr Steel, elected as Secretary in Buenos Aires, took on a much more active role than was customary in the commission. $\mathrm{Dr}$ Porubcan was added to the Organizing committee. Most of the Scientific highlights can be found in Reports on Astronomy Volume XXIIA 211-224, Edited by J.Bergeron. Copies were given to all members present. Members had also been kept informed of developements through regular Newsletters. The Acting President thanked Dr Duncan Steel for all his valuble assistance during the period, both with the production of the newsletters and the report. Other contributors to the report, Ceplecha, Porubcan, Jones, Hawkes, Grun, Koeberl and Baggaley were also thanked.

A written report on the activities of the working group on Professional -Amateur Cooperation was received from Dr Porubcan. A number of important point were made, 1. The benefit of holding joint Scientific meeting such as the ones in Smolinice Castle and in Bratislava,

2.The importance of sending reprints of papers on meteors from Professional journals to WGN so that abstracts could be published

3. That WGN is a good avenue for publishing suggestions for observing programmes.

4. The need to perhaps produce a new list of meteor showers- the "Cook" list is now very old and significantly in error for a number of stream mean orbits. It was resolved that the Working Group should continue its work and Dr Hawkes was elected to Chair the group in succession to Dr Porubcan. 
Prof Keay gave a brief report on the activities of the inter-Commission Working Group on the prevention of Interplanetary Commission, having taken the chair over from Iwan Williams following the death ofJan Stohl. The meeting resolved that it would support the continuation of the working group.

Dr Lindblad gave a report on the activities of the Lund Meteor Data Center, where significant use of the material was being made by a growing number of astronomers. One concern was that the IAU in its foreward budget had not included financial support for the center from 1995 onwards. The Commision resolved that the I.A.U. be requested to maintain the modest level of financial support (currently SF 3300 per trienium) which had been granted in the past in order that the valuable role of the Lund Meteor Data Centrer be preserved.

The Acting President gave a report on the current state of the moves towards reorganization of the Union and its commission (Since that state subsequently changed drastically, no details are given)

\section{MEETING ON THE SESSION ON MONDAY AUGUST 22 at $14 \mathrm{~h}$.}

This meeting was primarily concerned with the election of officers and members of various committees. The following were elected

President

Vice-President

Secretary

Organizing Committee Babadzhanov (Tajikstan), Ceplecha (Czeck Republic) Grun (Germany), Hasegawa (Japan), Jones (Canada), Koeberl (Austria), Porubcan (Slovakia) and Steel (Australia).

Representitives on NEO Working Group:- Williams, Steel

Representitives on the Interplanetary Pollution WG:-Keay (chair), Steel, Ceplecha Pro-Am Working Group:-Hawkes (Chair), Porubcan, Steel, Mason, Terentieva, Hasegawa, Brown,Roggemans, Yoshida, Ocenas, Rendtel, Woods.

Existing Members of the IAU elected to Commission 22:- C.D.Murray

New IAU members elected to Commission 22:- Borovicka, Mann, Spurney, and Taylor,

Consultants electe:- G.Andreev, W. Jones, Kessler, Nagasawa, Nakamura, Obrubov, Voloshchuk, Zook, Brown, Roggemans, Yoshida, Ocenas, Ohtsuka, Rendtel, Wood, Poole, Watanabe, Adolfsson, Asher,Wu.

The Commission expressed support for the new restructuring proposals feeling that the proposals were a considerable improvement on previous proposals and could be beneficial in improving the contribution of the IAU to Astronomy. Details of the proposals will be found elswhere but the main proposals involved the formation of about 10 divisions consistng of commissions with similar interests. The Divisions would be run by a board consisting in the case of commission 22 of the Presidents of each commission. The Division can elect its own President either from the existing commission Presidents or other suitable and distinguished members. Commission 22 resolved to affiliate to Division 3- Planetary System Studies. 